\title{
CHARACTERISTICS AND CHALLENGES OF THE HUNGARIAN STARTUP ECOSYSTEM
}

In this paper, the authors' aim to explore the Hungarian startup ecosystem on both the demand side and the supply side. To achieve this, they conducted a survey reaching both startups and investors. In the survey, the authors observed features of Hungarian startup entrepreneurs such as gender, age, education, previous entrepreneurial experience, and their motivation for establishing startup companies. Furthermore, the authors focused on financing, location, target markets, employment, and operational difficulties. They also examined the attitudes of the startupers and of the ecosystem's other actors such as venture capital investors, incubator houses, accelerators, corporations and co-working spaces regarding various characteristics of the ecosystem. They deemed cooperation between the members of the ecosystem, international relations and the opportunity for startupers to start again after a failed startup to be the most important characteristics. They perceived the strongest characteristic of the Hungarian ecosystem to be social events (meetups and networking), while the most problematic: the opportunity to start again after failing a startup and the required level of entrepreneurial administration'.

Keywords: startup, SME, startup ecosystem, venture capital, accelerator, incubator

$\mathrm{N}$ owadays the existence and continuous development of startup ecosystems are phenomenons that can be observed in all Central and Eastern European countries. The development program of 2014-2020 boosts the startup ecosystem in Hungary due to the expansion of available financial resources. One of the long-term strategic goals of the Hungarian government is to develop the startup ecosystem; therefore, it also actively participates as a financier at the venture capital market. It has established Hiventures from the former Corvinus Venture Capital Fund Management, which has become the biggest government-owned venture capital fund management in Hungary. It is essential that government-owned or private venture capital (VC) fund management companies know and understand their target group, the startupers.

Jáki and Molnár (2017a) gave an overview of the Hungarian venture capital market, the volume of investment at the venture capital funds, and the theoretical background of the government intervention. They compared the government-owned and private venture capital fund management in terms of their main operational characteristics. As government involvement can be justified by the existence of market failures, Jáki et al. (2017) investigated them in more detail. They defined three main market failures at the venture capital market: the asymmetric information regarding the business plan; the high transaction costs during the evaluation of investment opportunities; and the externalities produced by a new startup such as job creation or regional development. Räikkönen et al. (2016) show that the consideration of sustainability and profitability in investments can be combined successfully. Jáki and Molnár (2017b) focused on the model of the Hungarian VC market. They showed how state subsidies are distributed to target companies and summarized the history of the Hungarian VC market with its most important milestones. The main characteristics of startup ecosystems have been under investigation for many years now. The aim of our exploratory research is to determine the main characteristics of Hungarian startupers and investors in 2017.

All startup companies need a supporting ecosystem for rapid development and easy access to global markets, which is usually only available in big cities. Several studies investigate the beneficial factors that encourage the founding of new enterprises. Roman et al. (2018) found a significant correlation between macroeconomic figures (GDP), demographic variables (population growth rate), and the spirit of entrepreneurship. Besides macroeconomic and demographic features, other factors and events can support startup entrepreneurs naturally. According to our survey, actors of the Hungarian startup ecosystem found the following factors particularly useful: community events, co-working offices, startup competitions and the availability of mentors and consultants in Hungary. Likewise, Timilsina et al. (2016) found positive and significant relationships between the business environment, competitiveness, and firm performance. However, they also added, that one should put more emphasis on competitiveness to improve firm performance instead of blaming the business environment.

The most important actors of the Hungarian startup ecosystem are the startup companies themselves supported by incubator houses and accelerators who can provide access to their networks, consultancy services and occasionally financial resources as well.

To get to know the startupers, first, we have to define what a startup company is. We have found different

\footnotetext{
Jelen publikáció az EFOP-3.6.3-VEKOP-16-2017-00007 azonosítószámú „Tehetségből fiatal kutató - A kutatói életpályát támogató tevékenységek a felsőoktatásban" címü projekt keretében jött létre.
} 
definitions for startups based on the 2016 V4 reports (Dzurovčinová, 2016; Kollmann et al., 2016; Skala Kruczkowska, 2016; Staszkiewicz - Havliková, 2016) and based on the Digital Success Program created by the Hungarian government (Cabinet Office of the Prime Minister, 2016). We found the most appropriate definition to be the one used in the Program: "startup means a new company with high growth potential or a project team starting the process of becoming a business and preparing for the entry to the market" (Cabinet Office of the Prime Minister, 2016, p. 22.). Even though a uniform definition is missing, in startup ecosystem studies the final selection of startups was based on self-categorization. According to this, only those companies were involved in the surveys, which defined themselves as a startup and they were not investigated further whether they were corresponding to pre-determined definitions.

When trying to distinguish incubator houses and accelerators, there is always confusion not only about their names but also about their provided services. This is why we do not distinguish these two actors in our survey. Incubator houses and accelerators support startups in implementing their business idea with training and with their business network to find the right mentor or get access to the international market. Certain accelerators and incubator houses - in return for a small equity share - occasionally even provide capital for the startup company (Lovas - Riz, 2016). It is becoming common, that venture capital investors establish accelerators to finance the most promising enterprises from their own seed funds.

In our research, investors were represented by the CEOs of the Venture Capital (VC) fund management companies. They manage the VC funds, which are a form of accumulated capital without its own legal entity. The investment is made from the fund by the VC fund management company, which is represented by the investment managers who first evaluate the investment opportunity, namely the business plan of the startups.

Co-working spaces are shared working environments where entrepreneurs can work side by side, thus potentialyly generating some synergy from sharing their experiences with each other while working. Large corporations are also interested in the startup ecosystem since many of the innovations that can be used in their industries come from this sector. They run programs to help startupers, and potentially benefit from their innovations when it matches their profiles.

\section{Methodology and database}

Our study was conducted with the participation of Hungarian startups and venture capital investors, accelerators, incubator houses, corporations, and co-working spaces. The survey ran for a period of one month, from 15th of August to 20th of September 2017. The questionnaire contained multiple-choice and open-ended questions and we used SPSS for the analysis.

Our aim was to ask the whole population (census method) at the same time. The sampling method used for the survey was nonprobability convenience sampling, where the researcher makes an effort to reveal the whole population of the startup ecosystem and makes them fill out the questionnaire. For reaching the startups, we made use of one of the biggest startup databases: Crunchbase. The Crunchbase database contained 200 registered Hungarian startup companies in August 2017, to whom we sent our survey. The startup CEOs and founders were invited to participate via e-mail. Our survey was completed by 66 startup companies.

For reaching the VCs, we approached The Hungarian Private Equity and Venture Capital Association (HVCA), which represents the interests of the private equity and venture capital sector in Hungary. There were 26 Venture capital investors registered in HVCA at the time of our study and 14 of them agreed to fill out our survey.

We wanted to also reach the Hungarian incubator houses and accelerators. There is no sharp boundary between these two types of supporting entities. We managed to reach almost all the incubator houses and accelerators in Hungary with 25 respondents. There are less than 10 co-working spaces in Hungary, and we managed to reach 3 of them, 2 in Budapest and 1 in Györ. We also managed to reach 4 large corporations involved in the ecosystem, 2 from Szeged, 1 from Györ and 1 from Debrecen.

\section{Research question}

Since startups are required to be scalable, IT startups secured a leading position among their peers. Thus, it is easy to assume that most startupers come from an IT background, are somewhat lacking in business and finance skills and need help to make their business plan, to secure financing, and to determine their company's value. We formulated 9 research questions (Table 1) to explore the Hungarian startup ecosystem.

\section{Table 1. Research questions}

RQ1: What are the key demographic characteristics of Hungarian startupers?

RQ2: What are the main motivational factors of Hungarian startupers according to the age and gender

of startup founders?

RQ3: What do startups consider the main challenges of scaling their company?

RQ4: What is the job creation potential of Hungarian startups?

RQ5: What are the main financial sources that fund Hungarian startups?

RQ6: Which factors do the startup ecosystem members deem the most important in a startup

ecosystem?

RQ7: Are there significant differences between the opinions of the ecosystem member subgroups

about the importance of these factors?

RQ8: How do the startup ecosystem members rate the Hungarian startup ecosystem along the different characteristics?

RQ9: Are there significant differences between the opinions of the ecosystem member subgroups about the evaluation of these factors in Hungary? 
We want to find out who the Hungarian startupers really are, what motivations drove them to the startup scene, what are their biggest challenges and where do they get their financing (RQ1-3, RQ5). It is also useful to look at the job creation potential of Hungarian startups since job creation is often used to justify government intervention at the startup financing market, which is very prevalent in Hungary (RQ4).

On the other hand, we were also interested in the Hungarian startup ecosystem as a whole, more specifically, what factors do the ecosystem members deem important in a startup ecosystem and how do they rate the Hungarian ecosystem along these factors (RQ6-9). We approached $\mathrm{VC}$ investors, accelerators, incubators, co-working spaces and corporations to help illuminate this topic.

\section{Characteristics of the Hungarian startupers}

In this section, we try to answer RQ1: what are the key demographic characteristics of Hungarian startupers? Let's look at the startupers' characteristics who participated in our survey as we try to answer this question.

Based on the results of the questionnaire, entrepreneurs of start-up companies were typically between the age of 26-35 (38\%) and 36-50 (42\%) altogether representing $80 \%$ of total startupers. Only $9 \%$ of startupers were between the age of 19 25 and $11 \%$ were above 50 years. Korosteleva and Mickiewicz (2011) also examined the age distribution of startup entrepreneurs and found that the financial scale of the project increases with the age of the entrepreneur. This finding indicates that higher experience, established reputation, and accumulated savings of older entrepreneurs increase the chance of successfully collecting financial sources.

According to our survey, $86 \%$ of startupers were male and only $14 \%$ female, thus women are heavily underrepresented among the startupers. This is, however, an international trend as based on the research of European start-up Monitor from 2016, the ratio of female startup founders is only 14,8\% in Europe (Kollmann et al., 2016). Investigating the gender composition further, we found that in $32 \%$ of the cases, at least one female founder was present in the respondent startup teams.

According to our survey, $83 \%$ of the startupers have a higher education degree. 53\% have a master's degree. Within the segment holding the master's degree, 6,1\% also has a Ph.D. degree and $7,6 \%$ has an MBA degree. $16,7 \%$ of the respondents of startupers indicated that they are still a student at a secondary school. As can be seen on the following chart, the highest education level of the majority of startupers is MA/ MSc (39\%), followed by BA/BSc (30\%). Entrepreneurs with only secondary education represent a significant portion too (17\%), while entrepreneurs with Ph.D. or MBA only represent $6 \%$ and $8 \%$ of responder startupers. Based on the self-reported motivations of startupers we think that this distribution can be attributed to the following. Our respondents are generally not happy with the corporate lifestyle that they are forced into and the level of compensation relative to their company's profit, this is one of the motivating factors for launching their startup. Additionally, they crave more creative freedom. These are signs that these startupers previously worked or presently work in subordinate positions with relatively lower pay in the company, having to do repetitive tasks. These people generally have BA/BSc and MA/MSc degrees, and they feel that they are capable of higher-level tasks than the ones they are asked to do in their corporate jobs. On the other hand, only a small percentage of startupers have an MBA degree, which can be attributed to the fact that many MBA degree holders are in higher level managerial positions, where they must use all their skills and energy. Ultimately, they have no energy and motivation left for other professional projects, such as startups. $\mathrm{Ph}$.D. holders are very occupied as well having to constantly write new research papers, teach at their university and usually perform consultation and teaching outside the university too, this explains why only a small portion of startupers have Ph.D. degrees (Herzberg, 2017) (Figure 1).

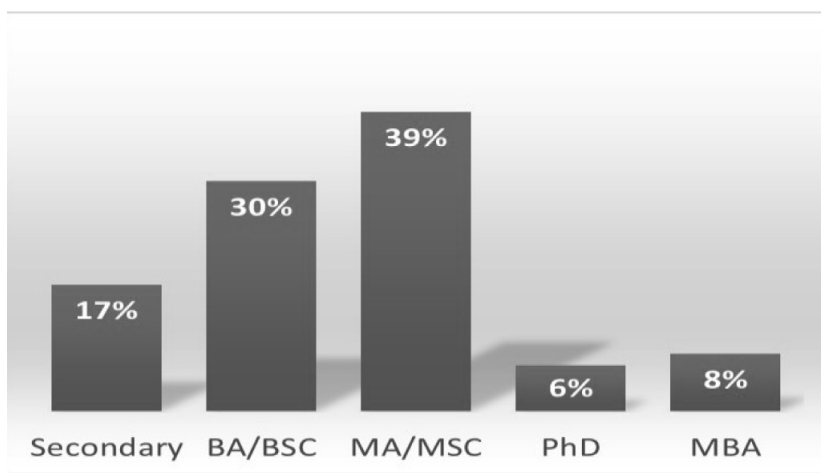

Figure 1 The highest education level of startupers in the Hungarian Startup Ecosystem (Source: own database)

Based on our survey, $47 \%$ of the Hungarian startupers graduated in the field of social sciences. Within the field of social sciences, respondents from economic sciences represent $64 \%$, marketing 9\%, general business studies $6 \%$ finance $10 \%$ and $11 \%$ graduated from other fields. Engineering represents a significantly smaller segment of qualifications $-22,7 \%$, information technology represents $10,6 \%$, and finally the arts and natural sciences both represent 3\% (Figure 2).

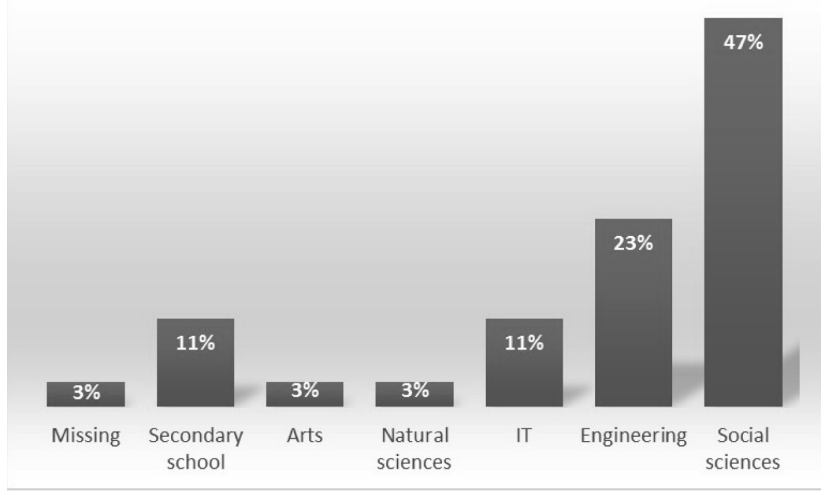

Figure 2 Startupers' areas of education (Source: own database)

The startupers believe that the most important skills and knowledge to launch a successful start-up are as follows: general business knowledge, project management, 
marketing. PR knowledge, and sales skills. They also regard the following fields crucial: legal, information communication technology, big data, and business analyses.

$79 \%$ of the respondent startups were founded and operate in Budapest. Miskolc (7\%) is the second most favored place to establish a startup company. Overall, only $21 \%$ of the respondents chose a city that is not the capital (Figure 3).

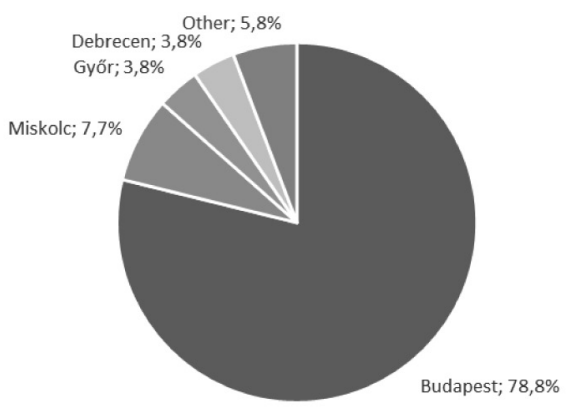

Figure 3 Headquarters of the startups (Source: own database)

Actors of the Hungarian startup ecosystem found $\mathrm{Bu}-$ dapest the most attractive city in the CEE region, followed by Prague, Bratislava (Pozsony) and Vienna but Warsaw, Krakow and Berlin were mentioned as well. Regarding the Hungarian cities, the respondents found Budapest the ideal location, followed by Debrecen and Györ. We can conclude based on our survey that Hungarian startupers are mainly men from Budapest holding a BA/BSc or MA/MSc degree from the fields of social sciences, engineering and IT (RQ1).

\section{Motivation for establishing a startup}

We now examine the differences in motivations for launching a startup according to the age and gender of startup founders (RQ2). Based on the answers, we distinguished the following motivational categories:

- Young and bold,

- Mission-sense,

- Self-actualization,

- Autonomy, independence.

Table 2 and 3 contains the results for the male and female subsamples. However, since there were 57 male and only 9 female respondents among the startups, the generalizability is much greater in the male subsample.

Table 2. Motivation for launching a startup - women

\begin{tabular}{|c|c|}
\hline $\begin{array}{c}\text { Age/ } \\
\text { Gender }\end{array}$ & Women $(\mathbf{n}=\mathbf{9})$ \\
\hline $19-25$ & $\begin{array}{c}\text { Young and bold: "More freedom and } \\
\text { free time", "to have a challenging job" }\end{array}$ \\
\hline $26-35$ & $\begin{array}{c}\text { Self-actualization: crave for success, } \\
\text { come up with an idea }\end{array}$ \\
\hline $36-50$ & $\begin{array}{c}\text { Self-actualization: "Based on my experience, } \\
\text { I had an innovative idea." or "I believe in my } \\
\text { idea which should be realized." }\end{array}$ \\
\hline
\end{tabular}

\begin{tabular}{|c|l|}
\hline \multicolumn{2}{|c|}{ Table 3. } \\
\hline $\begin{array}{c}\text { Age/ } \\
\text { Gender }\end{array}$ & \multicolumn{1}{c|}{ Men (n= 57) } \\
\hline $19-25$ & Young and bold \\
\hline $26-35$ & $\begin{array}{l}\text { Self-actualization: "I want to realize my } \\
\text { idea", "addiction to do something new." "to } \\
\text { put my dream into practice", "to have a good } \\
\text { group to work with" } \\
\text { Mission-sense: "to create something perma- } \\
\text { nent, everlasting" }\end{array}$ \\
\hline $36-50$ & $\begin{array}{l}\text { Autonomy, independence: "to get a higher } \\
\text { share from the profit", "being fed up with the } \\
\text { corporate lifestyle" } \\
\text { Mission-sense: "to make something valuable" } \\
\text { Self-actualization: "to realize an idea", } \\
\text { "I am a born entrepreneur" }\end{array}$ \\
\hline
\end{tabular}

Based on the answers about motivation, it is useful to investigate how experienced a startup entrepreneur is. Partly, they are fed up with the atmosphere of multinational companies. Stadnicka and Sakano (2017) show that multinational companies should motivate their employees to be a part of innovation and value creation, but this behavior is hardly recognizable in the Hungarian scene. In the age group of 36-50, some male respondents identified themselves as „born entrepreneurs" which can indicate that entrepreneurs in this age group reached the pinnacle of their craft. Regarding the entrepreneurial experience, it is important to know whether the startupers have taken part in a failed startup or not. $40 \%$ of the startupers participated in at least one failed startup but only $14 \%$ participated in more than one.

Another indicator of a "born entrepreneur" or the entrepreneurial experience is the current occupation of the startuper. The respondent could choose from the following answers: I am a student; I am a freelancer; I am doing my startup besides my full-time job; I am involved in one or more businesses; my startup is my full-time job. Based on the answers, $35 \%$ of the startupers count his startup as a full-time job and $25 \%$ are involved in more than one startup. $17 \%$ of them manage their startup besides their full-time job. Only $9 \%$ of them deal with the business besides their higher education studies and $14 \%$ of them are freelancers.

\section{Scaling strategy}

The scaling strategy of a startup is the plan for increasing the number of customers on the national, regional and global levels while keeping the marginal costs low. In this section, we examine what do startups consider the main challenges of scaling their business (RQ3). Startups typically provide a service to their customers via the internet and through client computing devices (PC, tablet, smartphone). It is easier to "scale" by providing internet-based services/products than physical products. When increasing the sales volume of IT services/products, the main additional cost is the purchase of new servers or new customer service staff. Meanwhile, if a manufacturing company wants to increase its sales volume, it has to install new production lines or even build new factories, all of which take a sig- 
nificant amount of investment. The marginal cost of creating physical products is also much higher than the marginal cost of an IT startup. Consequently, startups can grow their customer base and revenue with relatively low additional investments, assuming their product or service can be scaled, and the company has an appropriate scale strategy.

It is another question, whether it is beneficial to the whole economy that the main type of funded startups is the IT startup. This restricts many novel business ideas from realization which would require a substantial workforce. This fact, unfortunately, limits the job creating potential of the classic startup, which we will examine in more detail in the next section. The other issue with the dominance of IT startups is the increased difficulty that hardware startups face when seeking financing. It is much more costly for hardware startups to develop the prototype, they generally have lower profit margins and lower scalability. Hardware startups thus increasingly utilize crowdfunding to secure financing, rather than to compete with software startups for VC financing. Government sponsored VC investors could help hardware startups to get funded, expanding the job creating potential of the startup sector.

In our survey, $73 \%$ of startupers stated that they possess a scaling strategy. The greatest challenges of a scaling strategy were considered the following: financing, penetrating new markets and the lack of distribution channels. As Hungary is a small and open economy, it is essential for startups to penetrate external markets to achieve economies of scale within the investment period. Based on our survey, most of the Hungarian startupers thought that access to international markets has the greatest impact on the growth potential of their company. Consequently, $50 \%$ of startupers marked the following activities as priorities for the next year: increasing the sales volume and penetrating new markets. Even though most of the startups plan to extend their operation abroad, only $10 \%$ of the respondents stated that they have at least one foreign founder. $60 \%$ of startupers also need assistance to enter foreign markets.

On the one hand, startups must concentrate on their sales activity. On the other hand, the product or service needs constant development, particularly in the first 1-3 years. Product development was also mentioned by $50 \%$ of the companies as a main priority in the next year. In our survey, we used multiple choice questions to determine the area where startupers believe that they need assistance (Figure 4).

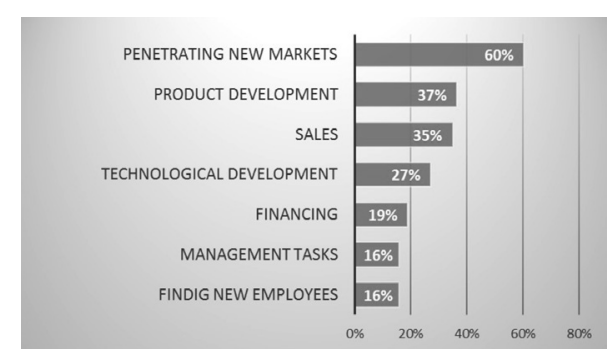

Figure 4 Activities where the startupers need assistance (Source: own database)

The activity where most startupers need assistance is entering new markets. This is followed by product development, sales growth, and technological development. Only $19 \%$ would like to use external help in raising funds and just $16 \%$ need assistance in organizational development and workforce expansion. Further results correspond with the findings in the educational part of the study. About 50\% graduated in the field of general business science and only $11 \%$ in the field of information technology. This explains why the startupers are looking for assistance with the product and technological development in a large part. According to our survey, $20 \%$ of startupers considered Hungary their main market and $70 \%$ think that their product/service will be in demand on the global market. Startup founders should make sure to have at least one technical expert who is responsible for the development of the product or service among the founders at the very start of the project.

\section{Job creation}

A well-known positive externality of startups is job creation. It is one of the positive externalities that are frequently used to justify government intervention at the startup financing market (Jáki - Molnár, 2017a). Job creation happens not only by hiring new employees at a startup, but the founders of the startup themselves can also be considered as employed. We now investigate the job creation potential of Hungarian startups (RQ4). According to our survey, 35\% of startup companies have more than two founders, $38 \%$ have two founders, and $27 \%$ have only one (Figure 5).

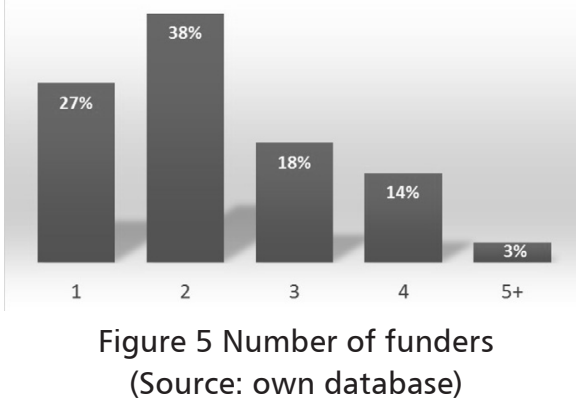

Only $21 \%$ of the startups did not have any employees. Traditionally, in the earliest stage of development, the founders do all the work, and they hire new employees as the firm grows. Most surveyed startups (43,9\%) employ 1 to 3 people. This company size is typical for early-stage startups. Although, 18,2\% of the surveyed startups have more than 10 employees, which indicates that there are a fair number of startups in an advanced stage of development at the Hungarian market. Particularly, two startups had a substantial number of employees - 40 and 50 -, this company size can be usually reached only after several rounds of investment (Figure 6).

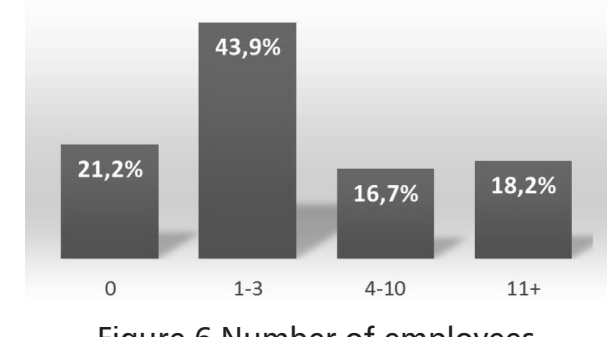

Figure 6 Number of employees (Source: own database) 
Regarding the nationality of the employees, $90 \%$ of the startups employ Hungarians only, while $10 \%$ employ foreigners too. This seems to indicate that Hungarian startups want to strengthen their international relations through agents primarily outside their company's employees - such as consultants or mentors.

Now let's look at the future employment plans of the startups. $23 \%$ of the surveyed startup companies want to employ new staff right now, $69 \%$ of them plan to hire new employees in 6 months or sooner, and $88 \%$ of them plan to recruit new employees within a year. These numbers show the job creation potential of the startup sector (Figure 7).

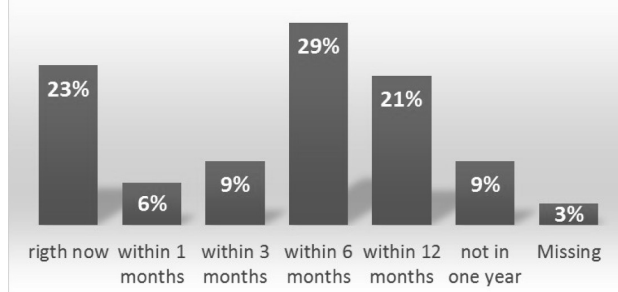

Figure 7 When do startups plan to hire new employees (Source: own database)

\section{Financing}

Now we investigate what financing sources do Hungarian startups use (RQ5). In our study, the following development phases of the startups were distinguished:

1) Idea/concept phase,

2) Beta version/prototype and product validation,

3) Early revenue generation,

4) Expanding/growing revenue generation,

5) Mature company.

Based on our research, incubator houses and accelerators support startup companies from the earliest phase when only a business idea is available and there isn't even a prototype yet. However, VC investors prefer startups in a more mature stage, preferably in the phase of early revenue generation, followed by expanding/growing revenue generation and the phase when the startup possess merely a beta version or a prototype of the product, but the product is validated.

Aman and Lovas (2015) also found that venture capitalists typically finance small and medium-sized enterprises with high growth potential. Venture capital investors prefer companies that already generate revenue and are in their growth phase. Lovas and Riz (2016) found that incubators, accelerators, business angels are willing to support startups in an earlier phase, but they are also looking for companies with high growth potential. They expect merely a developed product/service and support the startup to introduce their product into the market.

In our survey, $52 \%$ of the startup participants have already generated revenues, and are potential investment targets for venture capital investors. Furthermore, 35\% of startups have a beta version/prototype that can achieve support and funding from accelerators/incubator houses (Figure 8).

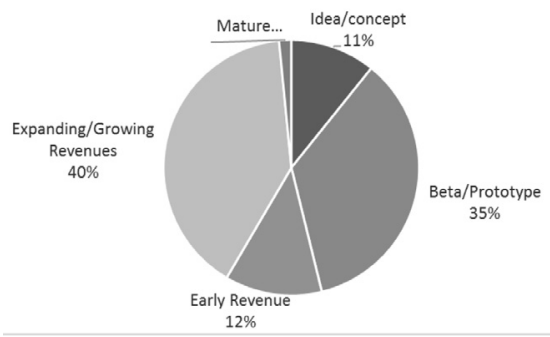

Figure 8 Maturity of Hungarian Startups (Source: own database)

Regarding the size of the requested share for the capital invested, most of the investors indicated the range $0-50 \%$. We can conclude that they typically leave the majority ownership in the hands of the original owners and they acquire only a minority interest in the companies. Accelerators typically require a smaller share in return for their investment than venture capital funds. Only a small fraction of the stakeholders mentioned that they require occasionally majority ownership.

As we have seen, startup entrepreneurs are typically middle-aged, so they may have accumulated savings. $17 \%$ of them work full time and $75 \%$ are committed to one or more startup businesses simultaneously. Financing is considered as the biggest challenge for implementing the long-term scaling strategy. Connection to the financers and acquiring the necessary information were mentioned as the biggest difficulties in fundraising. The additional difficulty is the length of execution. We found that $86 \%$ of entrepreneurs started their business from their own savings and $27 \%$ of founders received capital from their family members or friends. Only $24 \%$ of the start-up companies raised their capital from VC investors, 9\% mentioned business angels. A bank loan is not a significant source of funding, just a small number $(3 \%)$ of respondents reported receiving financing from banks. Not surprisingly, as these companies are typically not mature enough for commercial bank loans (Figure 9).

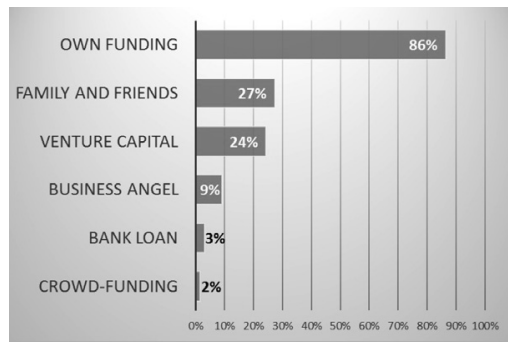

Figure 9 The main initial financing source of startups (Source: own database)

All startups must develop their product and service in their first years which demands new financial resources constantly. The investigated startups are on different levels of maturity; therefore, they can appeal to different financers. Figure 10 shows that $30 \%$ of the startupers try to involve $\mathrm{VC}$ investors in their business. 9\% appeals to angel investors and only $6 \%$ plan to turn to family members or friends for new financing sources. 


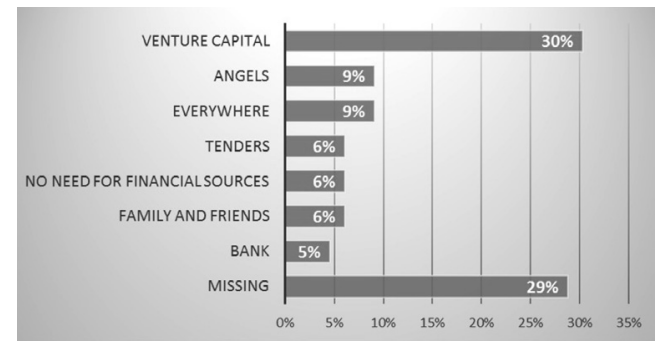

Figure 10 Where do the startupers search for new financing sources?

(Source: own database)

Crowdfunding has not played an important role in Hungary so far, only $2 \%$ of startupers reported to use it. However, Liu and Wang (2018) reflect the advantages of crowd-funding. Their study shows that firms due to the crowdfunding acquire more accurate market feedback regarding their new product than firms which are financed by Venture Capital funds. The result of our investigation corresponds with the findings of Dong and Men (2014), who stated that the availability of external funding sources for young, small and non-manufacturing companies are limited. These characteristics are appropriate to a typical Hungarian start-up as well.

\section{Evaluation of the startup ecosystem}

One aim of our study was to uncover what qualities do the members of the Hungarian startup ecosystem deem the most valuable (RQ6) and how strongly do they feel that these qualities are present in Hungary (RQ8). Thus, we asked the respondents to rate the importance of 15 startup ecosystem characteristics on a 1-5 Likert scale, where $(1)=$ not important at all, (2) = of little importance, (3) = of average importance, (4) = very important, and (5) = absolutely essential. We also asked them to rate the characteristics of the Hungarian startup ecosystem on a 1-5 Likert scale, where (1) = very poor, $(2)=$ poor, (3) = acceptable, (4) = good, and (5) = very good.

Likert scales present a set of items that can be used to measure a trait, such as satisfaction, these scales have equally spaced numbers (most typically 1-5) and equally spaced anchors. The Likert scale is also known as an aggregated scale, which means that multiple Likerttype items that measure the same characteristic can be evaluated together in an aggregated form. The consensus among statisticians is that Likert scales can be considered continuous variables for the purposes of analysis, as long as the assumptions of the given analysis method are fulfilled (Harpe, 2015). However, Labovitz (1967) also showed that analyzing Likert-type items that are linear and monotonic can be done with a low associated error. In studies where it is more advantageous to analyze the individual Likert-type items (questions) rather than the combined Likert scale, interval-based statistics are used (Aranyossy et al., 2018).

We will be looking at the sample mean, median, mode and the frequency of (4) and (5) answers, to assess the responses regarding the importance and evaluation of the startup ecosystem characteristics. Additionally, to be able to determine if the different startup ecosystem subgroups have differing opinions on any of the factors, we employed first a one-way ANOVA test on all the factors to see if there are any significant differences between the sub-groups on a 5\% significance level. After this, for the factors that had significant difference among the groups, we employed the Hochberg post-hoc test, which handles samples with different sizes of sub-samples very well, assuming homogeneity of variance between the sub-samples, which we have. This test lets us see exactly which sub-groups have significantly differing opinions regarding the importance and evaluation of the characteristics. The central tendency measures are showing similar results for the factors in Table 4 and Table 5 which are consistent with the frequency of the (4) and (5) answers.

\section{Importance of the startup ecosystem characteristics}

To answer RQ6, let's look at the importance that ecosystem participants attach to the different factors (as seen in Table 4). We can identify 4 groups using the central tendency measures as guidelines:

1) Inclination for cooperation among the members of the ecosystem, international relations, advanced entrepreneurial culture, access to funding and access to sufficiently educated workforce dominate the list, with the first item being the highest rated in terms of the mean and the frequency of (4) and (5) answers. In this context, advanced entrepreneurial culture included the opportunity for failed startupers to start again. It is surprising to see, how categorically accepted this characteristic is among the ecosystem participants, even considering the relatively high percentage that startupers represent in our sample. All the elements of this group have medians and modes of 5 , and a mean of equal to or greater than 4,25 .

2) The second group consists of the presence of successful startupers in the community as mentors, or angel investors; the number of high-quality ideas or projects; favorable tax environment for entrepreneurs; and favorable level of required administration for entrepreneurs. This group has median and mode values of 4 and 5 and a mean greater than 4.

3) The third group includes access to mentors, advisers, coaches; access to entrepreneurial education; social events (meetups, networking); and technology transfer. The members of this group have mean values between 3 and 4 .

4) The lowest importance group consists of the presence of co-working spaces and startup competitions. These items have medians and modes of 3 and a mean $\sim 3$. It 
is interesting to note how high the ecosystem members rated the importance of access to funding compared to how low they rated the importance of startup competitions. This may reflect that the primary channel for startupers to meet investors is not considered being exposed to them during a startup competition, but alternative, possibly more pro-active methods.

To answer RQ7, if we look at the tests for significant differences among the startup ecosystem member sub-groups (Table 6), we see that the one-way ANOVA detected significant differences associated with the presence of co-working spaces and the favorable tax environment for entrepreneurs. The importance of the presence of co-working spaces was rated significantly higher by the representatives of co-working spaces than by investors and startupers. It is natural that agents overestimate their own importance in any ecosystem, but the below average importance rating by the startupers themselves is rather surprising. Regarding the importance of favorable tax environment for entrepreneurs, startupers rated this characteristic significantly higher than incubators and accelerators. This can be attributed to the fact that the startupers themselves feel the financial burden of managing a startup each and every day, while those members of the ecosystem that are more focused on providing help and coaching for the startupers focus more on inner factors that can be improved and less on external factors.

\section{Evaluation of the startup ecosystem characteristics}

Now let's continue with our analysis of how the members of the ecosystem rated the characteristics of the Hungarian startup ecosystem (RQ8). Based on Table 5, the following groups of characteristics can be identified using the central tendency measures as guidelines:

1) The top characteristic forms a group in itself based on the distance between itself and the second most highly rated factor in terms of the central tendency measures and also the frequency of (4) and (5) answers. This characteristic is the social events (meetups, networking), which has a median and mode of 4 and a mean of 3,71 .

2) The second group consists of the presence of coworking spaces; startup competitions; the number of high-quality ideas or projects; and the access to mentors, advisers, coaches. Members of this group have median and mode values of 3 and means between 3 and 3,5. It is surprising that the presence of co-working spaces and startup competitions were rated as the least important factors in a startup ecosystem by the respondents, meanwhile, these two are also rated among the most strongly developed characteristics at the Hungarian ecosystem. It should also be noted, that the rating of this group despite almost being on the top of the list is only around average.

3) The third group includes the presence of successful startupers in the community as mentors, or angel investors; access to funding; and inclination for cooperation among members of the ecosystem. The median and mode of this group is 3 , and the means of factors in this group are between 2,8 and 2,9. Despite the cooperation between ecosystem members being the most important single characteristic, and access to funding being one of the most important characteristics, the rating of these at the Hungarian ecosystem are slightly below average. Building cooperation between the ecosystem members can happen organicalyly throughout the evolution of a startup ecosystem, which can happen in Hungary as the ecosystem matures. Policymakers can also consider how they can help speed up the process, according to our survey, organizing more startup competitions is not the answer. Also, despite the governmental venture capital initiatives in recent years, such as the Jeremie program and the creation of the Hiventures VC fund manager, ecosystem members still feel that the access to funding is slightly below average in Hungary. It is possible that there are other factors prohibiting the startupers from taking advantage of the large capital supply accessible at the market, such as a lack of skill in presenting their idea and convincing investors.

4) The next group contains technology transfer; access to sufficiently educated workforce and international relations. Members of this group have median and mode values of 2 or 3 and means between 2,6 and 2,7.

5) The bottom group contains four factors: access to entrepreneurial education; favorable tax environment for entrepreneurs; advanced entrepreneurial culture (opportunity to start again after failing a startup); and favorable level of required administration for entrepreneurs. Members of this group have medians and modes of 1 and 2 and means below 2,5. In developed startup ecosystems, investors consider having failed startups a sign of entrepreneurial experience on behalf of the startuper, and formerly we saw how highly the Hungarian ecosystem members valued the importance of this characteristic. It is disconcerting to see how underdeveloped this entrepreneurial culture is in Hungary, maybe this is something that policymakers should try to strengthen. On the other hand, entrepreneurial education on universities is heavily subsidized by the state, but still ecosystem members feel it to be poorly accessible. This could be attributed to the fact that at universities entrepreneurial education is mostly theoretical, and the practical parts consist mostly of pre-planned exercises and case studies. It is possible, that ecosystem members want an education that is more focused on creating actual new ventures, led by experienced entrepreneurs providing assistance with the process. This could be perceived as a pre-incubation, practice-driven educational process.

When we look at the significant differences between the ecosystem member sub-groups regarding the evaluation of the factors (RQ9) in Table 6, we see that there are two factors where we can find such differences. The first is the evaluation of access to funding at the Hungarian startup ecosystem. Particularly, startupers rate 
this characteristic significantly lower than incubators and accelerators. This can be explained by the professional experience difference between these groups. Ecosystem members already assisting the development of startups have substantial entrepreneurial experience, and they possibly undervalue the effort it took them to get their entrepreneurial education. On the other hand, fresh startupers might feel this education harder to get due to their proximity in time to attaining it.

Table 4. Importance of the startup ecosystem characteristics

\begin{tabular}{|c|c|c|c|c|c|c|c|}
\hline & \multirow{2}{*}{ Mean } & \multirow{2}{*}{ Median } & \multirow{2}{*}{ Mode } & \multirow{2}{*}{$\begin{array}{c}\text { Std. } \\
\text { Devia- } \\
\text { tion }\end{array}$} & \multicolumn{2}{|c|}{$\begin{array}{l}95 \% \text { confidence } \\
\text { interval of mean }\end{array}$} & \multirow{2}{*}{$\begin{array}{l}\text { Very important } \\
\text { (4) and absolu- } \\
\text { tely essential (5) } \\
\text { frequency }\end{array}$} \\
\hline & & & & & Lower & Upper & \\
\hline \multirow{5}{*}{$\begin{array}{l}\text { Inclination for cooperation among members } \\
\text { of the ecosystem } \\
\text { International relations } \\
\text { Advanced entrepreneurial culture } \\
\text { Access to funding } \\
\text { Access to sufficiently educated workforce }\end{array}$} & 4,42 & 5 & 5 & 0,855 & 4,250 & 4,590 & 87 \\
\hline & 4,39 & 5 & 5 & 0,852 & 4,221 & 4,559 & 82 \\
\hline & 4,29 & 5 & 5 & 0,957 & 4,100 & 4,480 & 83 \\
\hline & 4,25 & 4,5 & 5 & 0,892 & 4,073 & 4,427 & 79 \\
\hline & 4,25 & 4,5 & 5 & 0,947 & 4,062 & 4,438 & 83 \\
\hline \multirow{4}{*}{$\begin{array}{l}\text { Presence of successful startupers in the } \\
\text { community as mentors, or angel investors } \\
\text { Number of high-quality ideas or projects } \\
\text { Favorable tax environment for entrepreneurs } \\
\text { Favorable level of required administration } \\
\text { for entrepreneurs }\end{array}$} & 4,22 & 5 & 5 & 0,970 & 4,028 & 4,412 & 76 \\
\hline & 4,19 & 4 & 5 & 0,907 & 4,010 & 4,370 & 79 \\
\hline & 4,18 & 4 & 5 & 0,968 & 3,988 & 4,372 & 80 \\
\hline & 4,14 & 4 & 5 & 0,975 & 3,947 & 4,333 & 74 \\
\hline \multirow{4}{*}{$\begin{array}{l}\text { Access to mentors, advisers, coaches } \\
\text { Access to entrepreneurial education } \\
\text { Social events (meetups, networking) } \\
\text { Technology transfer }\end{array}$} & 3,93 & 4 & 4 & 1,066 & 3,718 & 4,142 & 73 \\
\hline & 3,88 & 4 & 5 & 1,225 & 3,637 & 4,123 & 67 \\
\hline & 3,72 & 4 & 3 & 0,944 & 3,533 & 3,907 & 56 \\
\hline & 3,59 & 4 & 4 & 1,065 & 3,379 & 3,801 & 55 \\
\hline \multirow{2}{*}{$\begin{array}{l}\text { Presence of co-working spaces } \\
\text { Startup competitions }\end{array}$} & 2,97 & 3 & 3 & 1,087 & 2,754 & 3,186 & 29 \\
\hline & 2,96 & 3 & 3 & 1,205 & 2,721 & 3,199 & 35 \\
\hline
\end{tabular}

Table 5. Evaluation of the startup ecosystem characteristics

\begin{tabular}{|c|c|c|c|c|c|c|c|}
\hline & \multirow{2}{*}{ Mean } & \multirow{2}{*}{ Median } & \multirow{2}{*}{ Mode } & \multirow{2}{*}{$\begin{array}{l}\text { Std. De- } \\
\text { viation }\end{array}$} & \multicolumn{2}{|c|}{$\begin{array}{l}95 \% \text { confidence } \\
\text { interval of mean }\end{array}$} & \multirow{2}{*}{$\begin{array}{l}\text { Good (4) and } \\
\text { very good (5) } \\
\text { frequency }\end{array}$} \\
\hline & & & & & Lower & Upper & \\
\hline Social events (meetups, networking) & 3,71 & 4 & 4 & 0,820 & 3,547 & 3,873 & 61 \\
\hline \multirow{4}{*}{$\begin{array}{l}\text { Presence of co-working spaces } \\
\text { Startup competitions } \\
\text { Number of high-quality ideas or projects } \\
\text { Access to mentors, advisers, coaches }\end{array}$} & 3,33 & 3 & 3 & 0,995 & 3,132 & 3,528 & 38 \\
\hline & 3,24 & 3 & 3 & 0,911 & 3,059 & 3,421 & 40 \\
\hline & 3,08 & 3 & 3 & 1,079 & 2,866 & 3,294 & 32 \\
\hline & 3,03 & 3 & 3 & 0,893 & 2,853 & 3,207 & 27 \\
\hline \multirow{3}{*}{$\begin{array}{l}\text { Presence of successful startupers in the } \\
\text { community as mentors, or angel investors } \\
\text { Access to funding } \\
\text { Inclination for cooperation among members of } \\
\text { the ecosystem }\end{array}$} & 2,88 & 3 & 3 & 0,967 & 2,688 & 3,072 & 29 \\
\hline & 2,87 & 3 & 3 & 1,116 & 2,649 & 3,091 & 30 \\
\hline & 2,81 & 3 & 3 & 0,982 & 2,615 & 3,005 & 22 \\
\hline \multirow{3}{*}{$\begin{array}{l}\text { Technology transfer } \\
\text { Access to sufficiently educated workforce } \\
\text { International relations }\end{array}$} & 2,68 & 3 & 3 & 0,898 & 2,502 & 2,858 & 11 \\
\hline & 2,67 & 3 & 3 & 1,035 & 2,465 & 2,875 & 19 \\
\hline & 2,61 & 2 & 2 & 0,973 & 2,417 & 2,803 & 18 \\
\hline \multirow{4}{*}{$\begin{array}{l}\text { Access to entrepreneurial education } \\
\text { Favorable tax environment for entrepreneurs } \\
\text { Advanced entrepreneurial culture } \\
\text { Favorable level of required administration for } \\
\text { entrepreneurs }\end{array}$} & 2,22 & 2 & 2 & 1,021 & 2,017 & 2,423 & 11 \\
\hline & 2,11 & 2 & 1 & 1,024 & 1,907 & 2,313 & 11 \\
\hline & 2,09 & 2 & 1 & 1,083 & 1,875 & 2,305 & 11 \\
\hline & 1,96 & 2 & 1 & 0,994 & 1,763 & 2,157 & 8 \\
\hline Evaluate the domestic startup ecosystem & 2,91 & 3 & 3 & 0,900 & 2,731 & 3,089 & 22 \\
\hline
\end{tabular}


Table 6. Comparison of sub-sample means (ANOVA and

Hochberg at $\alpha<5 \%$ )

\begin{tabular}{|c|c|c|c|c|c|c|}
\hline & $\begin{array}{l}\text { One- Way } \\
\text { A NOVA } \\
\text { Sig }\end{array}$ & Sub-group & $\begin{array}{l}\mathrm{S} \text { u b - } \\
\text { sample } \\
\text { mean }\end{array}$ & Sub-group & $\begin{array}{l}\mathrm{S} \text { u b - } \\
\text { sample } \\
\text { mean }\end{array}$ & $\begin{array}{l}\text { Hochberg } \\
\text { Sig }\end{array}$ \\
\hline \multirow[t]{2}{*}{ Importance of the presence of co-working spaces } & \multirow[t]{2}{*}{0,018} & investors & 2,636 & $\begin{array}{l}\text { co-working } \\
\text { space }\end{array}$ & \multirow[t]{2}{*}{4,667} &, 035 \\
\hline & & startups & 2,828 & $\begin{array}{l}\text { co-working } \\
\text { space }\end{array}$ & & ,036 \\
\hline \multirow{3}{*}{$\begin{array}{l}\text { Importance of a favorable tax environment for ent- } \\
\text { repreneurs } \\
\text { Evaluation of access to funding at the Hungarian star- } \\
\text { tup ecosystem } \\
\text { Evaluation of access to a sufficiently educated work- } \\
\text { force at the Hungarian startup ecosystem }\end{array}$} & 0,005 & startups & 4,414 & $\begin{array}{l}\text { incubators, } \\
\text { accelerators }\end{array}$ & 3,583 & ,003 \\
\hline & 0,011 & startups & 2,586 & $\begin{array}{l}\text { incubators, } \\
\text { accelerators }\end{array}$ & 3,333 &, 046 \\
\hline & 0,030 & investors & 3,273 & corporations & 1,500 &, 030 \\
\hline
\end{tabular}

The second characteristic is the evaluation of access to a sufficiently educated workforce at the Hungarian startup ecosystem. Corporations rate this significantly lower than investors. Corporations have an interest in the startup scene in supporting startupers to innovate in their industry, in the hopes of acquiring those startups when their development level reaches a sufficient level. It is very likely that corporations base this rating on their own subjective experience when it comes to finding and hiring an educated workforce, and they project this onto startups. Investors, on the other hand, have a closer relationship to startups and possibly see the situation in a more realistic way.

\section{Summary}

In conclusion, we can say that the Hungarian startupers are generally men in their middle years from Budapest, who have experience at multinational companies or as an entrepreneur. Almost half of them have already taken part in a failed startup. Only a small fraction of our respondents are students at a university. Overall, startupers have a qualification in business sciences (marketing, finance or economics) at least as BA students. In the case of the younger generation, the main motivation for launching a startup is to have more freedom and challenge. For older respondents, motivation comes from a kind of burn-out. Many of them are opposed to the culture of multinational companies. In general, the middle-aged groups want to "re-establish" themselves and to realize their innovative idea. Startupers need external help the most with entering new markets, product development, and sales activity. Startups have substantial job-creating potential, as almost all of our respondents indicated that they plan to hire new employees within a year.

We also examined how the members of the startup ecosystem - startupers, VC investors, incubators and accelerators, corporations, and co-working spaces - think about the importance of the ecosystem's characteristics and how they evaluated these characteristics in the Hungarian ecosystem. They deemed the cooperation among the ecosystem members, international relations, and the opportunity for startupers to start again after a failed startup the most important characteristics. The presence of coworking spaces and startup competitions were rated as the least important. They also feel that co-working spaces and startup competitions are overrepresented in the Hungarian startup ecosystem compared to their perceived importance. They found social events (such as meetups and networking) to be the strongest characteristic of the Hungarian ecosystem. On the other hand, access to entrepreneurial education; favorable tax environment for entrepreneurs; advanced entrepreneurial culture (opportunity to start again after failing a startup); and favorable level of required administration for entrepreneurs were found to be the weakest characteristics of the Hungarian ecosystem.

In the paper, we presented general findings that help to understand the startups' behavior and characteristics and collected the key factors of the development of the startup ecosystem. Our research helps startup entrepreneurs, policymakers, and various investors to understand the actual market situation, problems, and challenges that startupers currently face.

\section{References}

Aman, S. - Lovas, A. (2015): Overcoming Asymmetric Information in Venture Capital Finance: Theoretical approach and evaluation of Hungarian findings. Studies in International Economics: Special Issue of Külgazdaság, 1(2), pp. 3-22.

Aranyossy, M. - Blaskovics, B. - Horváth, Á. A. (2018): How universal are IT project success and failure factors? Evidence from Hungary. Information Systems Management, 35(1), pp. 15-28. doi: 10.1080/10580530.2017.1416943.

Cabinet Office of the Prime Minister (2016): Digital Startup Strategy of Hungary. Retrieved from: http:// www.kormany.hu/download/2/4b/21000/The\%20Digital\%20Startup $\% 20$ Strategy\%20of\%20Hungary.pdf (Accessed: 2018.12.01)

Dong, Y. - Men, C. (2014): SME Financing in Emerging Markets: Firm Characteristics, Banking Structure and Institutions. Emerging Markets Finance and Trade, 50(1), pp. 120- 149. doi: 10.2753/REE1540-496X500107

Dzurovčinová, P. (2016): Slovak Startups Report 2016. Retrieved from: https:/www.slideshare.net/PetraDzurov- 
cinova2/slovak-startups-report-2016-part-of-v4-startupsurvey-1-71950526 (Accessed: 2018.12.01)

Harpe, S. E. (2015): How to analyze Likert and other rating scale data. Currents in Pharmacy Teaching and Learning, 7(6), pp. 836-850. doi: 10.1016/j.cptl.2015.08.001.

Herzberg, F. (2017): Motivation to work. Abingdonon-Thames, UK: Routledge

Jáki, E. - Molnár, E. M. (2017a): Állami és uniós szerepvállalás a magvető életszakaszban lévő vállalkozások kockázatitőke-finanszírozásában. in: Farkas B. - Pelle A. (eds.): Várakozások és gazdasági interakciók. Szeged: JATEPress Kiadó, pp. 97-110. ISBN: 978-963-315-348-2.

Jáki, E. - Molnár, E. M. (2017b): Model of the state and EU involvement in the venture capital market. in: Zoltayné P. Z. - Horák P. - Váradi K. - Zwierczyk P. T. - Vidovics Dancs Á. - Rádics P. J. (eds.): ECMS 2017: 31st European Conference on Modelling and Simulation, Nottingham: ECMS - European Council for Modelling and Simulation, pp. 120-126. ISBN: 978-0-9932440-4-9.

Jáki, E. - Molnár, E. M. - Walter, Gy. (2017): Government Sponsored Venture Capital: Blessing Or Curse? Management (SLOVENIA), 12(4), pp. 317-331. doi: 10.26493\%2F1854-4231.12.317-331.

Kollmann, T. - Stöckmann, C. - Hensellek, S. - Kensbock, J. (2016): European startup Monitor 2016, Essen, Germany: German Startups Association. ISBN: 978-3938338-17-9

Korosteleva, J. - Mickiewicz, T. (2011): Start-up Financing in the Age of Globalization. Emerging Markets Finance and Trade, 47(3), pp. 23-49. doi: 10.2307/23047087.

Labovitz, S. (1967): Some observations on measure- ment and statistics. Social Forces, 46(2), pp. 151-160. doi: $10.2307 / 2574595$.

Liu, H. - Wang, Y. (2018): The Value of Crowdfunding: An Explanation Based on Demand Uncertainty and Comparison with Venture Capital. Emerging Markets Finance and Trade, 54(4), pp. 783-791. doi: 10.1080/1540496X.2018.1434619.

Lovas, A - Riz, N. (2016): Accelerator or incubator?: Enterprise support organisations in Hungary in light of international practice. Economy and Finance, 3(4), pp. 305-322.

Roman, A. - Bilan, I. - Ciumas, C. (2017): What Drives the Creation of New Businesses? A Panel-Data Analysis for EU Countries. Emerging Markets Finance and Trade, 54(3), pp. 508- 536. doi: 10.1080/1540496X.2017.1412304.

Skala, A. - Kruczkowska, E. (2016): Polish Startups Report 2016. Retrieved from: http://startuppoland.org/wpcontent/uploads/2016/09/Startup-Poland-Raport-2016-03ENG.pdf (Accessed: 2018.12.01)

Stadnicka, D. - Sakano, K. (2017): Employees Motivation and Openness for Continuous Improvement: Comparative Study in Polish and Japanese Companies. Management and Production Engineering Review, 8(3), pp. 70-86. doi: 10.1515/mper-2017-0030.

Staszkiewicz, M. - Havliková, D. (2016): Czech Startups Report 2016. Retrieved from: https://www.aspeninstitutece.org/project/czech-startup-report/ (Accessed: 2018.12.01)

Timilsina, B. - Forsén, N. - Takala, J. - Malek, N. A. A. (2016): Which one to choose multi focus or trade-off among competitive priorities? Evidence from Finnish SMEs. Management and Production Engineering Review, 7(1), pp. 77-88. doi: 10.1515/mper-2016-0009. 